\title{
LANGSTROTH HIVE CONSTRUCTION WITH CEMENT-VERMICULITE
}

\author{
Maria Cristina Affonso Lorenzon ${ }^{1 *}$; Rodolfo Gonçalves Cidreira ${ }^{2}$; Edmundo Henrique Ventura \\ Rodrigues $^{3}$; Milton Sérgio Dornelles ${ }^{4}$; Geraldo Pereira Jr. ${ }^{2}$ \\ ${ }^{1}$ UFRRJ - Depto. de Reprodução e Avaliação Animal - Rod. 465, km 7, 23851-970 - Seropédica, RJ - Brasil. \\ ${ }_{3}^{2} U F R R J$ - Instituto de Zootecnia. \\ ${ }^{3}$ UFRRJ - Depto. de Arquitetura e Urbanismo. \\ ${ }^{4}$ UFRRJ - Depto. de Matemática. \\ *Corresponding author <lorenzon@ufrrj.br>
}

\begin{abstract}
Exfoliated vermiculite is a light-weight and cheap product that, because of its thermal resistance, has become a valuable insulating material. With regard to its use in beekeeping, this research tested whether the box for honey bees constructed with cement-vermiculite mortar (CVM) presents physical characteristics similar to those of wood. The experiment was carried out at Seropédica, RJ, Brazil, for eight months. The cement-vermiculite mortar was compared with a control material (pinewood), in the construction of Langstroth boxes and boards, in a completely randomized design, with respect to thermal control, thermal conductivity and its capacity to absorb and lose water. The production cost for a CVM box was estimated. There were no internal temperature differences between CVM and wooden boxes. Thermal conductivity values for CVM and pinewood were similar. CVM absorbed more water and lost water faster than pinewood. Since CVM boxes can be easily constructed, at a low cost and with similar characteristics as traditional boxes, made of wood, the material can be recommended for use in non-migratory beekeeping.
\end{abstract}

Key words: Apis mellifera, mineral, beekeeping, insulating material

\section{CONSTRUÇÃO DE COLMÉIA LANGSTROTH COM CIMENTO-VERMICULITA}

\begin{abstract}
RESUMO: A vermiculita expandida é um material leve, barato e sua resistência térmica permite sua utilização como material isolante. Referente ao seu uso na Apicultura, esta pesquisa testou se a caixa para abelhas melíferas construída com argamassa cimento-vermiculita (ACV) apresenta características similares às da madeira. O estudo foi realizado em Seropédica (ERJ), Brasil, durante oito meses. Comparou-se a argamassa com o material controle, que foi a madeira pinho, em caixas de abelhas e em placas, em um delineamento inteiramente casualizado, quanto ao: controle térmico, a condutividade térmica, a capacidade de absorver e perder água. O custo de produção da caixa ACV para abelhas foi estimado. Não se observaram diferenças da temperatura interna entre as caixas de ACV e de madeira. A condutividade térmica foi similar nas placas de ACV e de madeira. As placas de ACV absorveram mais água, mas perderam mais rapidamente do que as de madeira. Considerando que a caixa de abelhas ACV é de fácil construção, de custo baixo e apresenta características similares a do material tradicional (madeira), este material pode ser recomendado para a apicultura, desde que não migratória.
\end{abstract}

Palavras-chave: Apis mellifera, mineral, apicultura, material isolante

\section{INTRODUCTION}

Vermiculite is a mica-type mineral usually formed by hydrothermal alteration, such as biotite and phologopite (Addisson, 1995). Brazil has the world's third largest vermiculite reserve (IBGE, 2001), mainly in the states of Piauí, Goiás, Paraíba and Bahia (DNPM, 2003).

In its natural state, vermiculite has little practical application. However, after it is exfoliated, it becomes a low-density material with excellent thermal-insulating properties. These properties make exfoliated vermiculite a product with widespread application, especially in civil and naval engineering and for industrial use in general (Deer et al., 1996). The exfoliation phenomenon occurs when vermiculite is quickly heated to above $230^{\circ} \mathrm{C}$, allowing its crystalline structure to be folded and separated (Addison, 1995). Each exfoliated flake imprisons inert air cells in its interior, which imparts great insulating property to vermiculite. The product thus obtained is flameproof, odorless, has low-density, is non-irritant to the skin and lungs, does not conduct electricity, is a thermal insulator and acoustic absorbent, resistant to decomposition, does not attract insects, and can absorb up to five times its weight in water (Deer et al., 1996). 
Mortar is a material obtained by mixing an agglomerate, usually cement, with a fine aggregate, as quartzose sand, and water (Alves, 1986). Rodrigues et al. (1994) used several types of porous mortars as construction material, because of its low specific mass property. Among the porous mortars that can be applied, those containing foamy additives, with incorporation of plant fibers, such as cellulose, sugarcane bagasse, coconut, and sisal are worth noting. In addition, there exist mortars made with exfoliated minerals, such as vermiculite (Beraldo et al., 1991). The use of vermiculite as a fine aggregate to replace sand is known as cementvermiculite mortar. The specific weight of conventional mortar is $210 \mathrm{kN} / \mathrm{m}^{3}$; in vermiculite, this parameter ranges from 25 to $180 \mathrm{kN} / \mathrm{m}^{3}$ (Tezuca, 1989). Porous mortar is an alternative material that should be tested in several zootechnical facilities and equipment (Rodrigues et al., 1994).

In beekeeping industry, wood is the most frequently used beehive constructing material. This row material presents the most important characteristic as a suitable shelter for bees: has insulation property, keeping the internal temperature resistant to the ambient variations. This physical condition aids honey bees to maintain the thermal homeostasis of the colony, which is essential for its survival (Seely \& Heinrich, 1981).

Neves (2002) verified that empty Langstroth nucleos, constructed of 1:3 cement-vermiculite mortar, reached internal temperature similar to those observed in boxes made from wooden boxes. In continuing with this research, tests were conducted to verify whether some physical characteristics of boxes to honey bees made of cement-vermiculite mortar and of wood were similar or not. For this purpose it was evaluated some physical variations, the advantages and disadvantages of using this material during the construction of boxes and its handling in the apiary.

\section{MATERIAL AND METHODS}

The survey was accomplished from October through May, in Seropédica, Rio de Janeiro State, Brazil $\left(22^{\circ} 45^{\prime} 28^{\prime \prime} \mathrm{S}, 43^{\circ} 41^{\prime} 05^{\prime \prime} \mathrm{W}\right)$. The climate type in the region is AW, according to Köppen classification system.

Twenty boxes for honeybees were used: ten made of cement-verrmiculite mortar (CVM) box and ten made of wood. These boxes were 10-frame standard Langstroth model with, one nest and one super, all of the Hoffman frames were made of pinewood. The wooden boxes were purchased from a beekeeping store. All these boxes were made from $2 \mathrm{~cm}$ thick pinewood. After assembly, these hives were sanded and painted yellow (bottom, nest, and cover), and white (super), with three oil paint coatings.

CVM boxes were built by preparing a system consisting of molds, such as those presented by Neves
(2002), according to Figures 1 and 2. These molds were easily made, but should be followed the dimensions of 10-frame Langstroth model and they have to be polished to facilitate the release and for a better finishing of the molded parts. Before receiving the cementvermiculite mortar, the molds were previously moistened and coated with vegetable oil to facilitate the removal of boards from he mold. The mortar was prepared using medium grain vermiculite, from 4 to $5 \mathrm{~mm}$, cement, usually CPIIE 32 type, and water. A 1:3 mix proportion (by volume) was used, consisting of one part of cement to three of vermiculite, according to Rodrigues (1998). To prepare the mix, dry components (cement and vermiculite) were homogenized, then some water was added little by little, until the fingers marked the mixture. The mortar was gradually filling and compacted in the molds. After filling the molds with mortar, the material was left to dry in a shaded place for two days without sprinkling water and in the next three days it was sprinkled water twice a day. On the ninth day, the material was carefully removed by unscrewing the molds. The boxes parts were assembled partly by gluing and partly by fastening $3.5 \mathrm{~mm} \times 4.5 \mathrm{~cm}$ screws, into no. 5 bushings. The molds can be reused and all the tasks related can be made using basic carpenter. The CVM boxes followed the painting pattern used for the wooden boxes.
NEST
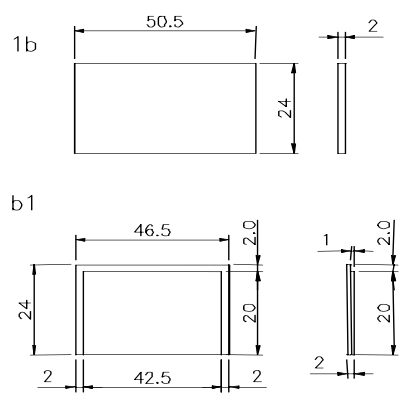

BOTTOM BOARD

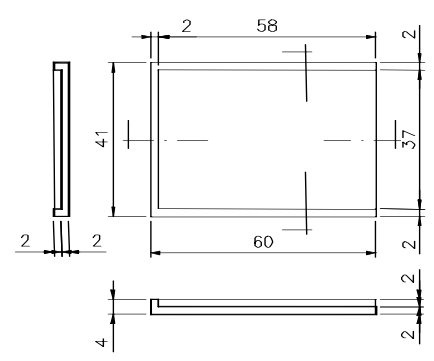

SUPER

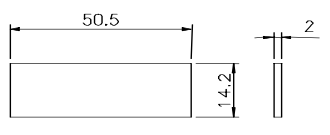

b2

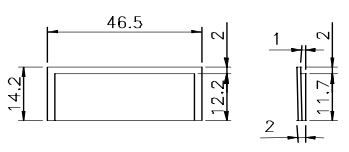

Figure 1- Molds for the side parts that support the nest (1b) and super frames (2b). Recess detail for nest (b1) and super (b2). 

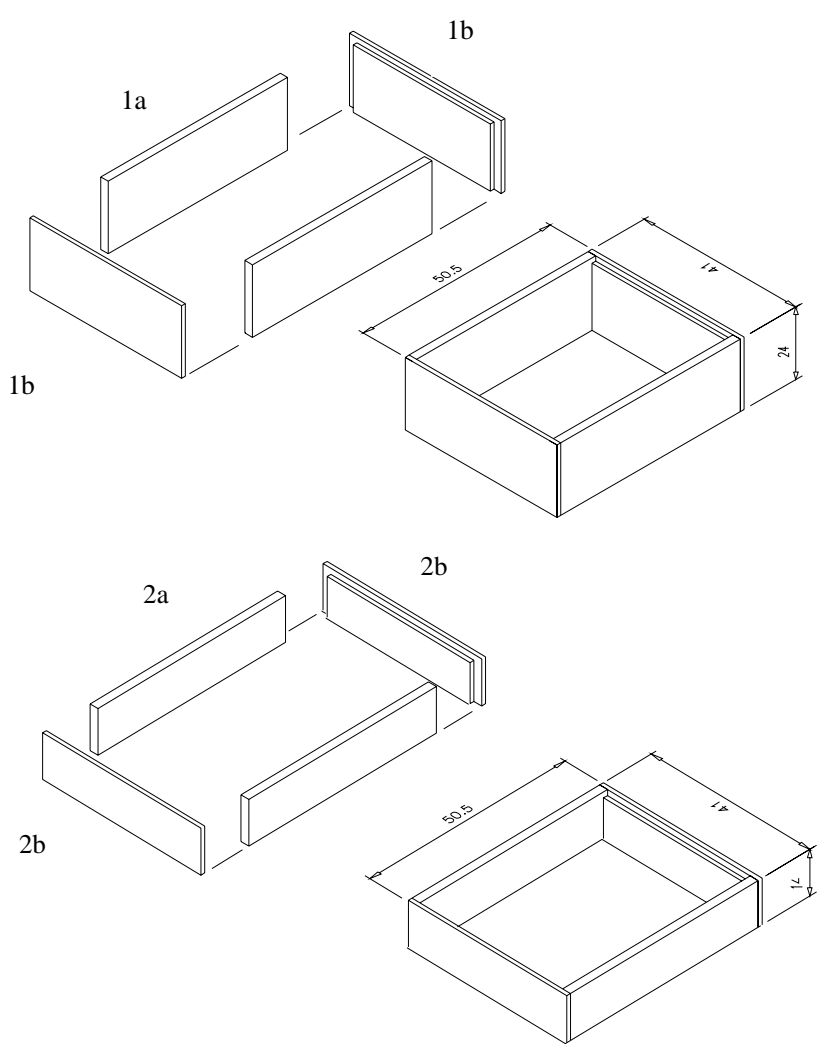

Figure 2 - Assembly of boards for Langstroth model nest (1a side and $1 \mathrm{~b}$ front) and super ( $2 \mathrm{a}$ side and $2 \mathrm{~b}$ front).

The boxes were assembled, weighed and installed in the apiary, at random, with entrances facing north, standing $0.5 \mathrm{~m}$ above the ground in individuals trestles, at a minimum distance of two meters from one another and protected by roofs covered with clay tiles. The boxes were opened every other week in the same manner as done by beekeepers, to verify possible damages due to environment and to management.

Some abiotic conditions, air temperature, relative humidity were measured weekly at 7 a.m., 10 a.m. and 1 p.m., 3 p.m., 5 p.m, using a psychrometer. The internal temperatures of the nest and super were measured every other week These data were monitored at 7 a.m., 10 a.m. and 1 p.m., 3 p.m. A digital thermometer, accuracy $0.1^{\circ} \mathrm{C}$, connected to a copper thermocouple, $35 \mathrm{~cm}$ long was used. The probe was inserted into a $1.5 \mathrm{~mm}$ hole that existed in the nests and supers of the boxes. The position of the sensor was standardized to be in the central part of the boxes, opposite the entrance. The internal temperature was analyzed at two levels: type of material (wood and CVM) and period (beginning and end) of the experiment; ANOVA and Tukey test were used to compare the means. The SAEG program (Sistema para Análises Estatísticas e Genéticas - System for Statistical and Genetic Analyses) was employed (UFV, 1997).
The following assay was conducted to determine thermal conductivity: six CVM and six pinewood boards considered as specimens were cut with the same size, measuring $7.0 \times 4.8 \times 2.0 \mathrm{~cm}$. These specimens were numbered and theirs masses were determined with an electronic balance, with a $0.01 \mathrm{~g}$ precision. After weighing, the mean mass for the specimens was obtained and the results were applied in the following equation, according to Rodrigues (1998): $\mathrm{k}$ (thermal conductivity) = $0,0003545 . \rho-0,007146$; where $\rho$ is the specific mass for the specific material (pinewood and CVM), which was determined based on the mass of the board material (in $\mathrm{kg}$ ) divided by the board volume (in $\mathrm{m}^{3}$ ) of each material being studied.

In order to determine the water absorption and loss rates, the masses of wooden and CVM boards were recorded before and after immersing them in a container with water for 30 minutes. The difference between mass measurements indicated water absorption by both materials. The specimens were then taken to a forced ventilation oven, where they were randomly arranged. The assay began at 8:00 a.m. and specimen mass measurements were made at 8:30 a.m.; 9 a.m.; 9:30 a.m.; 10:30 a.m.; 12:30 a.m., 4:30 p.m. and 00:30 a.m. This procedure was performed at $30^{\circ} \mathrm{C}$ and $55^{\circ} \mathrm{C}$, the first was near ambient temperature and the second represented a temperature routinely used in the laboratory. After weighing, the mean masses for the specimens of each material tested were obtained and the results were applied in the following equation: $\mathrm{WLC}(\%)=\mathrm{SB} / \mathrm{BT} \times 100$; where WLC represents water loss capacity (\%), SB is the saturated board mass ( $\mathrm{g}$ ) and BT is the board mass at a given time in minutes.

A completely randomized experimental design was adopted, with seven replicates. A linear regression between time (explanatory variable) and water loss capacity (response variable) was calculated for both studied temperatures, in order to indicate the best drying point for the boards. The production cost for the model Langstroth CVM box was detailed and compared with the mean prices of wooden boxes in the Brazilian southeastern region market.

\section{RESULTS}

The CVM boxes were easily made, but needed a certain care. Removal of boards from the molds and their assembly implied a 5\% loss of parts. After assembling and organizing the parts, the mean mass for a complete Langstroth CVM box was (18.47 \pm 0.24$) \mathrm{kg}$ and $(9.36 \pm$ $0.35) \mathrm{kg}$ for a wooden box.

CVM box was the most fragile during management, wear of the upper edges of the boxes was observed, especially between the upper part of the nest of the nest and cover, whose surfaces are routinely handled 
by beekeepers with tool hive. Cover and bottom board were more susceptible to be cracked especially if they were managed right after rainy days. With regard to the wooden boxes, two covers and four nests became warped and this material was more susceptible to environmental conditions and wax moth (Galleria mellonella and Achroia grisella) damages, although no material containing bee wax, which is attractive to these moths, was used. In the study site did not show problems with termite infestations and occasional burnings, but if they occurred, the wooden boxes could be more damaged.

The internal temperature means in the nests boxes were $(30.53 \pm 0.63)^{\circ} \mathrm{C}$ and $(31.22 \pm 0.79)^{\circ} \mathrm{C}$, for wooden boxes and CVM boxes, respectively. The internal temperature means in the supers were $(30.86 \pm$ $0.54)^{\circ} \mathrm{C}$ and $(31.01 \pm 0.63)^{\circ} \mathrm{C}$, for wooden boxes and CVM boxes, respectively. Internal temperature did not show differences with reference to the type of material, period or the interaction between these variables $(P \geq 0.01)$ (Table 1).

With reference to temperature and humidity fluctuations, it was verified that internal temperature fluctuations in the wooden and CVM boxes were similar (Figure 3 ).

Thermal conductivity for the CVM specimen was $0.32 \mathrm{wm}^{-1 \circ} \mathrm{C}$ and $0.19 \mathrm{wm}^{-1}{ }^{\circ} \mathrm{C}$ for the wooden specimen. The CVM specimen absorbed $21.30 \%$ of water, while the wooden specimen absorbed $13.68 \%$. In the water loss, the CVM specimen showed greater loss than the wooden specimen during most of the drying time $(P<0.01)$. In the final third of the drying period, the wooden specimen lost more water, because the CVM specimen was almost dry already $(P<0.01)$. This occurred at both temperatures tested $\left(30\right.$ and $\left.55^{\circ} \mathrm{C}\right)$ (Figures $4 \mathrm{~A}$ and $4 \mathrm{~B}$ ). At the $30^{\circ} \mathrm{C}$, water loss was slower than at $55^{\circ} \mathrm{C}$. The coefficients of determination between the time and water loss variables were high and significant. For the wooden specimen, $\mathrm{R}^{2}=0.97$ and 0.99 , while for the CVM specimen, $\mathrm{R}^{2}=0.96$ and 0.95 at the 30 and $55^{\circ} \mathrm{C}$, respectively.

Table 1 - Internal temperature of the nest and super of Langstroth boxes constructed of pinewood and cement-vermiculite mortar (CVM), along experimental time. Seropédica (UFRRJ), 2001/ 2002.

\begin{tabular}{|c|c|c|c|c|c|}
\hline \multirow{2}{*}{$\begin{array}{l}\text { Box } \\
\text { part }\end{array}$} & \multirow{2}{*}{$\underset{\text { Temperature }}{\text { Room }}$} & \multicolumn{2}{|c|}{ Wooden Box ${ }^{\circ} \mathrm{C}$} & \multicolumn{2}{|c|}{$\mathrm{CV}$ M Box ${ }^{\circ} \mathrm{C}$} \\
\hline & & Start & End & Start & End \\
\hline Nest & $29.83 \pm 2.48$ & $32.26 \mathrm{a}$ & $29.33 \mathrm{a}$ & $32.28 \mathrm{a}$ & $30.37 \mathrm{a}$ \\
\hline Super & $29.00 \pm 3.86$ & $31.88 \mathrm{a}$ & $30.55 \mathrm{a}$ & $31.44 \mathrm{a}$ & $30.68 \mathrm{a}$ \\
\hline
\end{tabular}

Tables 2 and 3 show the cost of the mold used to build the Langstroth CVM box and the cost for producing one CVM box with one super, respectively. Table 4 features a comparison between a complete Langstroth box, made of wood and CVM.

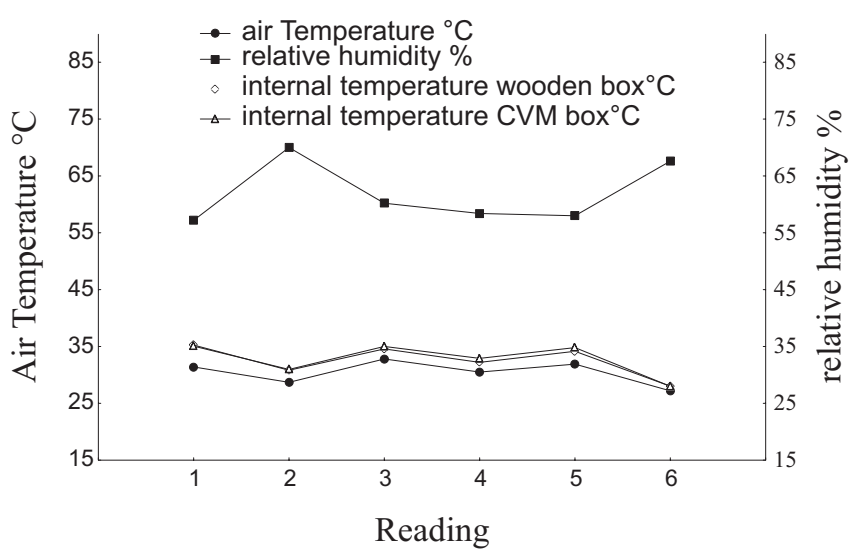

Figure 3 - Air temperature, relative humidity and internal temperature fluctuations in wooden and cementvermiculite mortar (CVM) boxes at the start and end of the experiment.

Table 2 - Producing cost of five molds made of wood and pinewood used to produce the bottom board, cover and three sides for the construction of a cementvermiculite mortar box. Seropédica (UFRRJ), $2001 / 2002$.

\begin{tabular}{lccc}
\hline Specification & Unit & Amount & Total Value US\$ \\
\hline Screw & part & 48 & 3.32 \\
Wood & meter & 06 & 3.88 \\
Labor* & day/man & 02 & - \\
\hline Total & & 7.20 \\
\hline Amortization per box built** & & 0.23 \\
\hline
\end{tabular}

*family labor; **the molds allow the construction of 40 parts

Table 3 - Producing cost of a Langstroth model cementvermiculite mortar (CVM) box for one super, without frames. Seropédica (UFRRJ), 2001/2002.

\begin{tabular}{lccc}
\hline Specification & Unit & Amount & Total Value US\$ \\
\hline Screws & part & 12 & 0.41 \\
No.5 plastic bushings & part & 12 & 0.25 \\
Cement & $\mathrm{kg}$ & 4 & 0.82 \\
Vermiculite & $\mathrm{bag}$ & $1 / 2$ & 2.16 \\
Glue (wood glue) & liter & 300 & 0.16 \\
Labor* & day/M & $1 / 2$ & - \\
Vegetable oil & liter & 200 & 0.16 \\
Amortization of molds*** & & & 0.23 \\
\hline Total & & & 4.20 \\
\hline
\end{tabular}

*family labor; **the molds allow the construction of 40 parts 

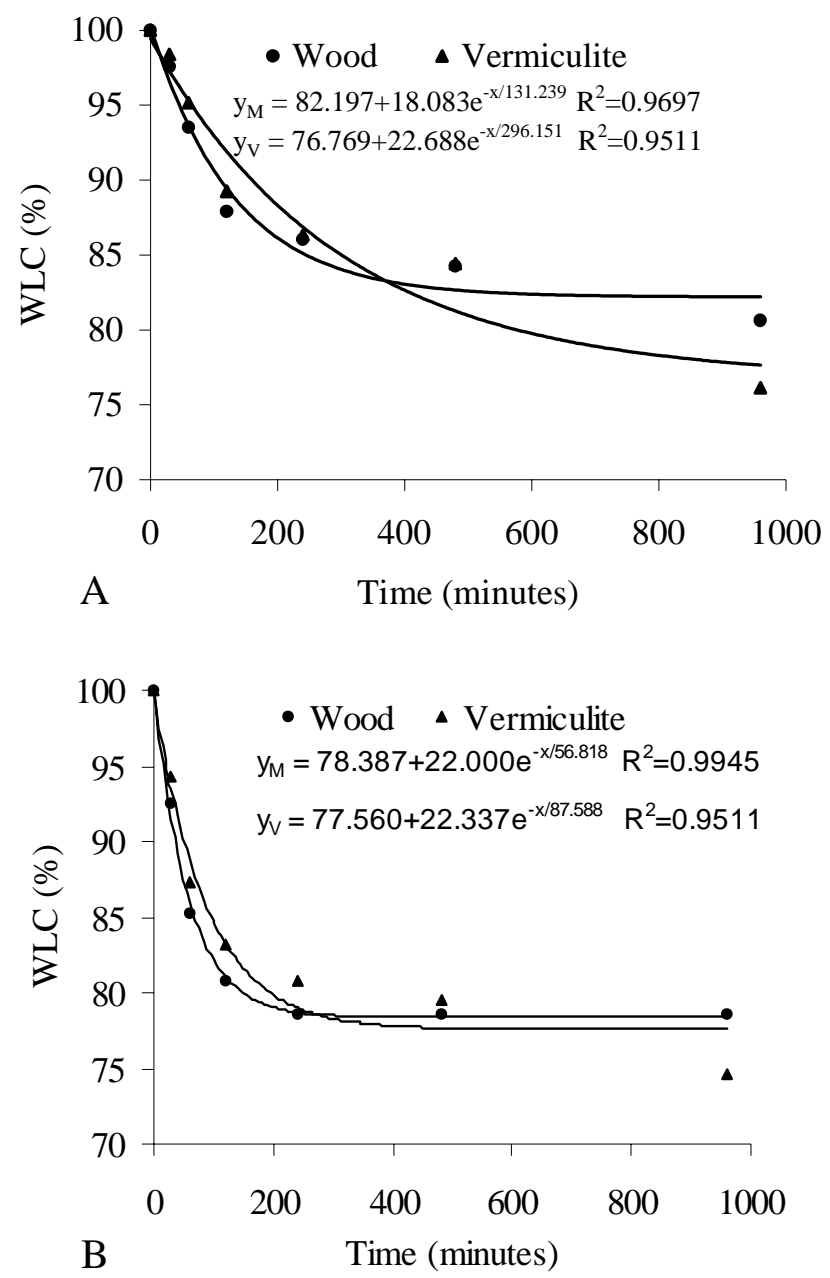

Figures $4 \mathrm{~A} / \mathrm{B}$ - Water loss from cement-vermiculite mortar (CVM) and wooden specimens obtained at seven times at $30^{\circ} \mathrm{C}(\mathrm{A})$ and $55^{\circ} \mathrm{C}(\mathrm{B})$.

Table 4 - Production cost of Langstroth model cementvermiculite mortar and wooden boxes for one super. Seropédica (UFRRJ), 2001/2002.

\begin{tabular}{lcc}
\hline Specification & Unit & $\begin{array}{r}\text { Total value } \\
\text { US } \$\end{array}$ \\
\hline A) Cement- vermiculite mortar box $(\mathrm{CVM})$ & \\
Super +10 frames & part & 4.35 \\
Nest +10 frames & part & 5.32 \\
Cover + bottom board & part & 1.10 \\
\hline Amortization, use of molds & & 0.23 \\
\hline Total & & 11.00 \\
\hline B) Wooden Box & part & 3.98 \\
Super +10 frames & part & 5.62 \\
Nest +10 frames & part & 5.64 \\
\hline Cover + bottom board & & 3.34 \\
\hline Unassembled box freight rate & & 18.58 \\
\hline Total & & \\
\hline
\end{tabular}

\section{DISCUSSION}

One of the important aspects when recommending a new material for building Langstroth hives to small beekeepers is that it should be easy to handle. Regarding this aspect, the CVM hive is produced as handcraft, using basic carpentry hand tools, including their molds, while wooden box construction normally requires specific machinery. Additional advantages in the construction of this box were a $40.79 \%$ reduction in cost relative to the price of a wooden box (Table 4) and a reduction of one dollar and 20 cents in relation to the ferrocement hive developed by Hobson (1983). A smaller vulnerability to the attack of wax moths is another important aspect, especially considering that the initial stage of colony development in the nest box is the most susceptible to the attack of these insects in hot regions. This type of box could be resistant to termites and burnings, which is a subject that needs to be investigated.

The disadvantages consist in the occurrence of fractures in some parts, the causes of which could be due to: the use of an excessively wet mix, deteriorated cement, incorrectly mixed mortar, mix compaction during molding, or carelessness during assembly. Some parts (cover and bottom) proved more vulnerable in the field and could crack when rains, a heavy roof is used, or crack during handling, requiring great care. In order to lessen this difficulties, it is recommended that a nylon or a wire screen should be used in one half of the mold during construction of the cover and bottom board. To reduce wear on the edges of the nest and super, it is recommended that their upper parts should be lined with a rubbery material, or with galvanized strips.

The CVM box mass is almost twice as heavy as the mass of the pinewood box, and it is practically identical to the mass of the ferrocement box reinforced by wire mesh (Hobson,1983), but it is much lighter than the masonry box, with a mass of $43.55 \mathrm{~kg}$ (Lengler et al., 2000). The weight and fragility of the CVM box are aspects that prevent it from being used in migratory beekeeping.

Even with a thermal conductivity greater than wood, the vermiculite in the mortar transfers its insulating property to the CVM box, allowing for internal temperature stability, since this material responds slowly to temperature and humidity fluctuations in the environment (Figure 3). This result was similar to that obtained by Padilha et al. (2001), who observed thermal conductivity values of 0.16 to $0.44 \mathrm{wm}^{-1}{ }^{\circ} \mathrm{C}$ in CVM boards. According to Stangenhaus (1992), the thermal conductivity of concrete is $1.50 \mathrm{wm}^{-10} \mathrm{C}$, and that of mortar cement is $1.15 \mathrm{wm}^{-10} \mathrm{C}$, which are values far from desired, making the use of vermiculite promising for hive construction. High temperature resistance is essential to 
maintain honey bee colonie in shelters, safe energy for homeostasis, which is vital for its survival (Hess, 1926; Himmer, 1927).

The greater absorption of water by CVM boards is an indication that during periods of intense rain CVM could present variations in its internal moisture degree, which is a limiting aspect as a physical trait in a shelter for honey bees. According to Free (1980), moisture in the brood area of the colony must be stable and should not be higher than $40 \%$. If the rainy period coincides with blooms that yield abundant nectar, the high humidity of the air, or even its saturation within the box, could increase the time required for honey to mature, delaying harvest and reducing its production during the bloom (Moritz \& Southwick, 1992). On the other hand, the greater loss of water in the CVM specimen (Figures 4A, 4B), also observed by Rodrigues (1998), could provide evaporative cooling by honey bees in the dry period, thus favoring honey maturation and temperature control. Thus, CVM boxes could be performed better in dry climates than humid. Even if the CVM specimen presents greater water loss than wood, internal moisture stability in the nest should be a crucial point when characterizing a shelter for honey bees. If that is the case, this material needs to be perfected. Tests could be conducted using hydrophobic vermiculite, developed by Martins (2002), or using moisture-resistant products as lining within the box.

In view of these results CVM box use as an additional alternative to small beekeeping, to regions that need wood extraction prevention. The physical responses were satisfactorily as honey bee shelter and their confined aspects can be rectified. Precautions must be taken to avoid losses during construction, and instructions to prepare them must be followed to the letter. The model consists of a fragile box, not allowing migratory beekeeping. The use of such material in permanent apiaries helps to prevent of vandals, which is common in certain regions, because the bottom of the hive can be cemented to the supporting concrete trestle. For reduce the moisture in the box, tests should be taken into account offering greater ventilation in the supers in humid tropical regions.

\section{ACKNOWLEDGEMENTS}

To Associação Brasileira de Cimento Potland $(\mathrm{ABCP})$, Fundação de Apoio à Pesquisa do Rio de Janeiro (FAPERJ) for financial support and to Henrique José Porto Serra for reviewing the English manuscript.

\section{REFERENCES}

ADDISSON, J. Vermiculite: A review of the mineralogy and health effects of vermiculite exploitation. Regulatory Toxicology and Pharmacology, v.21, p.397-405, 1995.

ALVES, J.D. A vermiculita como agregado para concreto. Goiânia: Ed. Universidade Federal de Goiás, 1986. 26p.

BERALDO, A.L.; NAAS, I.A.; FREIRE, W.J. Materiais para construções rurais. Rio de Janeiro: Ed. Livros Técnicos e Científicos, 1991. $167 \mathrm{p}$.

DEER, W.A.; HOWIE, R.A.; ZUSMAN, J. Minerais constituintes das rochas - uma introdução. Lisboa: Fundação Calouste Gulbenkian, 1996. 350p.

DEPARTAMENTO NACIONAL DE PRODUÇÃO MINERAL (DNPM). http://www.dnpm.gov.br. (04 jan. 2003).

FREE, J.B. A organização social das abelhas (Apis). São Paulo: EDUSP, 1980.79p.

HESS, W.E. Die temperaturregulierung im bienenvolk. Zeitschrift für Vergleichende Physiologie, v.4, p.465-487, 1926.

HIMMER, A. Ein Beitrag zur Kenntnis des Wämehaushalts im Nestbau Sozialer Hautflüger. Zeitschrift für Vergleichende Physiologie, v.5, p.375-389, 1927.

HOBSON JR., J.V. Ferrocement as a material for hives. Queensland Agriculture Journal, v.109, p.157-160, 1983.

INSTITUTO BRASILEIRO DE GEOGRAFIA E ESTATÍSTICA (IBGE) Anuário Estatístico. 2001.

LENGLER, S.; CASTAGRINO, G.L.; KIEFFER, C. Avaliação da temperatura interna de colméia de alvenaria e madeira. Informativo Zum Zum, v.34, p.14-15, 2000.

MARTINS, J. Vermiculita. http://www.uol.com.br/cienciahoje/chdia/ vol.159.htm. (04 jan. 2002).

MORITZ, R.F.A; SOUTHWICK, E.E. Bees as superorganisms: An evolutionary reality. New York: Springer-Verlag, 1992. 395p.

NEVES, J.O. Efeito de colméias construídas em argamassa de cimentovermiculita sobre o desempenho de abelhas africanizadas (Apis mellifera Linnaeus, 1758), na fase de estiramento. Rio de Janeiro: UFRRJ, 2002. 45p. (Dissertação - Mestrado).

PADILHA, J.A.S.; FILHO, R.D.T.; LIMA, P.I.L.; JOSEPH, K.; LEAL, A.F. Argamassa leve reforçada com polpa de sisal: compósito de baixa condutividade térmica para uso em edificações rurais. COMBEA, v.2, p.1-11, 2001.

RODRIGUES, E.H.V. Desenvolvimento e avaliação de um sistema evaporativo, por aspersão intermitente, na cobertura de aviários usando modelos de escala distorcida. São Paulo: UNICAMP/FEAGRI, 1998. 178p. (Tese - Doutorado).

RODRIGUES, E.H.V.; SILVA, D.D.; SILVA, J.B.; FIGUEIREDO, C.C. Desenvolvimento de uma argamassa para utilização em sistema de resfriamento evaporativo. In: CONGRESSO BRASILEIRO DE ENGENHARIA AGRÍCOLA, São Paulo, 1994. Anais. Campinas: SBEA, 1994. p.56.

SEELY, T.; HEINRICH, B. Regulation of temperature in the nests of social insects. In: HEINRICH, B. (Ed.) Insect thermoregulation. New York: John Wiley \& Sons. 1981. cap.3, p.154-234.

STANGENHAUS, C.R. Paredes, conforto higrométrico, edificações, ponderações e proposta para clima tropical úmido em situações de verão. Rio de Janeiro: UFRRJ, 1992. 199p. (Dissertação - Mestrado).

TEZUCA, Y. Concretos especiais. In: SIMPÓSIO DE DESEMPENHO DE MATERIAIS E COMPONENTES DE CONSTRUÇÃO CIVIL, 2., Florianópolis, 1989. Anais. Santa Catarina: Imprensa Universitária da UFSC, 1989. p.182-194.

UNIVERSIDADE FEDERAL DE VIÇOSA. Sistema de análises estatísticas e genéticas - SAEG (versão 5.0 ). Viçosa: UFV, 1997. 150p.

Received April 24, 2003

Accepted September 24, 2004 